JNUS:Journal of Nahdlatul Ulama Studies

Vol. 1, No.2, Juli 2020: p. 210-216. DOI: 10.35672/jnus.v1i2. 210-216

Website: http://jnus.lakpesdamsalatiga.or.id/index.php/jnus/index

\title{
Old Order, New Order, NU Order (Existence of NU Today)
}

\author{
Afidatul Asmar \\ Institut Agama Islam Negeri Parepare \\ afidatulasmar@iainpare.ac.id
}

\begin{abstract}
This paper attempts to explain the role and strategy of the Nahdlatul Ulama (NU) today, by making a comparison of the existence of the NU from the Old Order (ORLA), then in the New Order (ORBA) which finally according to the author produced the NU Order (ORNU). This research uses the library research method to answer the various ups and downs that lead to the design of the paradigm, methodology, and foundation of NU today. The results showed that the NU experienced ups and downs, becoming the largest Islamic organization during the Old Order. Then it became a political party during the New Order era. Then the final result explained that ORNU which was intended at this time was NU returned to their first goal of forming an NU organization to preach in the social and educational fields, not to engage in practical politics.
\end{abstract}

Keywords: Old Order, New Order, Current NU Order

\begin{abstract}
Abstrak
Tulisan ini berupaya menjelaskan peran dan strategi Nahdlatul Ulama (NU) pada masa kini, dengan menjadikan perbandingan eksistensi NU dari masa Orde Lama (ORLA), kemudian pada Orde Baru (ORBA) yang akhirnya menurut penulis menghasilkan Orde NU (ORNU). Penelitian ini menggunakan metode kepustakaan (library research) untuk menjawab berbagai pasang surut yang mengarah pada rancang bangun paradigma, metodologi, dan fondasi NU pada masa kini. Hasil penelitian menunjukkan bahwa masa NU mengalami pasang surut, menjadi organisasi Islam terbesar pada masa Orde Lama. Kemudian ikut menjadi partai politik dimasa Orde Baru. Kemudian hasil akhir menjelaskan ORNU yang dimaksudkan pada masa kini merupakan NU kembali pada tujuan pertama mereka membentuk organisasi NU untuk berdakwah di bidang sosial dan pendidikan, bukan terjun pada politik praktis.
\end{abstract}

Kata Kunci: Orde Lama, Orde Baru, Orde NU Masa Kini

\section{INTRODUCTION}

The dynamics of human life continue to develop. The development of human life can not only be completed with a rational-empirical approach, but also a religious normative approach (Abdullah, 1996). One of the religions that teaches the need to solve human life problems comprehensively is Islam as taught in Islamic jurisprudence which combines rational and normative elements. Islamic legal scientists argue that the legal problems faced by Muslims cannot only be solved by a legalistic normative approach, but must also use a rational empirical approach. Imam Syafii has practiced the existence of Islamic legal norms that developed based on the demands of the benefit of human life, so that he issued a legal 
JNUS: Journal of Nahdlatul Ulama Studies, Vol. 1, No. 2, Juli 2020: 210-216

opinion consisting of qaul qadim and qaul jadid even though the sources are both from the Al-Qur'an and Sunnah, but the object of figh law objectives is different. Imam al-Ghazali as one of the ushul fiqh scientists who has a substantive paradigm in the study of Fiqh (Islamic law) argues that the benefit of Muslims which is the main goal of the emergence of Islamic legal norms is based on dialectics between legalistic normative and empirical rational elements (Syarifuddin, 2009).

Islam as a religion and teaching system that has developed in Indonesia, has undergone a process of acculturation, transmission from generation to generation over a long period of time, and in a diverse cultural space, is an activity, and this process involves ulama ', habaib (descendants of Prophet Muhammad), and religious figures. in this country, so as to be able to create a stable dynamic life, tolerant and rahmatan lil alamin (Baharun \& Mundiri, 2011).

In connection with the diversity that exists in Indonesia, Abdul Karim stated that Pancasila is a source of national morality which is the result of a collaborative thought of community leaders and scholars (Karim, 2014). However, it does not mean that the presence of Pancasila is easily accepted by all circles in Indonesia. The period 1945-1980 was a period in which Pancasila fought with Islam as the basis of the state. This condition ended after in the 1980s Pancasila was confirmed as the philosophical foundation of this country (Maarif, 2017).

It needs to be understood that to make Islam rahmah lil alamin, the Prophet Muhammad invited mankind to embrace and practice Islam. The prophet's da'wah stretched out from the bitter Mecca period to the successful Medina period. In his long preaching experience, it appears that the prophet developed da'wah in the community gradually, starting from secret da'wah (sirriyah) with a personal approach, open preaching ('alamyah) with a collective approach, and political da'wah (siyasah) with an institutional approach. The preaching model at the time of the prophet needs to bring back its historical value and meaning in the times afterward, especially in today's modern Islamic world, including in Indonesia. (Asmar, 2018).

One of the largest organizations in Indonesia then appeared in guarding the long process of the effects of religion in the world and in Indonesia from the above period, namely Nahdlatul Ulama (NU). This organization has a moderate, appreciative intellectual tradition with legacy of the past and local culture, and has the ability to absorb new thought traditions that come from anywhere across national, religious and ideological boundaries. (Zahro, 2004). NU is also responsible for contributing by building the ideals of national civility. This is none other than because NU's contribution is not only addressed to NU congregations, but is bigger than that how NU can contribute to the nation (Zada \& Sjadzili, 2010). 
So that some of the latest developments in this country create its own challenges for Jamiyah Nahdlatul Ulama (NU), who may not be less severe (not to say heavier) than what he faced at the time of his birth decades ago. Why not, recently Indonesia has been flooded with several religious sects whose understanding is crucially opposed to the Ahlus Sunnah wal Jamaah (ASWAJA) ideology adhered to by NU, namely Shia, Wahabi, Hizbut Tahrir and the Liberal Islam Network. Ironically, they arrived at almost the same time so it seemed as if NU had been beaten up.

In another context, we will see how NU's long history has gone beyond a very long era with upheaval along with the founding of the Indonesian nation. This is what makes NU's unique struggle more on maintaining a good culture and applying religion properly and correctly. In accordance with the NU motto: Maintain what came from the past as long as it is good, and take better than what happened (Al-Muhafadzatu ala al-Qadim al-Shalih wa alAkhdzu bi al-Jadid al-Ashalah) (Bisri, 2002).

Related to the various approaches above, this library research intends to further elaborate and focus on the discussion of the latter approach, namely the current NU approach.

\section{RESULT AND DISCUSSION}

\section{NU during the Old Order}

Since the initial declaration of NU on January 31, 1926, NU's founding fathers immediately concentrated on the socialization of the newly founded mass organization to the wider community. In socializing NU to the community, it can be said that there are no significant difficulties. This is because NU already has a wide network through Islamic boarding schools that are not only limited to Java. The NU network which is based on the kiai network has been going on for a long time, long before NU was founded (Siradj, 2015).

Martin noted that NU's early pioneering period until 1942 was characterized by a growing number of followers and an unusually rapid geographic expansion. NU members are not registered systematically. Estimates of the numbers have also been volatile. By the mid1930s some 400 kiai were already members of $\mathrm{NU}$ and the total number of followers was estimated at 67,000 (Bakar, 1957).

Nahdlatul Ulama (NU) in every step of the way always prioritizes the interests of the nation, state and is always based on the basis of Islamic shari'at and Islamic values, also based on Indonesian values and a high spirit of nationalism, This can be seen how the background of the Nahdlatul Ulama was born, how it played such a big role in fighting for Indonesian independence and maintaining the integrity of the Republic of Indonesia. NU led by $\mathrm{KH}$. Hasyim Asy'ari highly upholds national values, nationalism based on Islamic syari'at 
'ala Ahl al Sunnah wal al-Jama'ah (Siddiq, 1985). The jihad carried out by scholars and their students is jihad to defend the country, as a form of love for the country (hubb al-watan) which is interpreted as jihad fi sabilillah. Because efforts to defend and enforce the Republic of Indonesia in the view of Islamic law are part of the religious obligations that Muslims must carry out. (Anam, 1999).

\section{NU during the New Order}

Islam has spread widely in Indonesia since the 13th century until the 19th century. Islam is increasingly spreading in Indonesia. At that time, pesantren began to exist in each region. However, the behavior of native santri and abangan santri is still difficult to distinguish because pre-Islamic mystical beliefs (kebatinan / kejawen) are still difficult to separate, because this is an old Indonesian culture brought by Hinduism and Buddhism. (Feillard, 1997).

During the 20th century, the world of students increasingly absorbed the abangan world. From these things, Islamic reform efforts began in this century with the aim of implementing Islamic teachings in a "truer" manner. In 1912 a religious organization was born which was also concerned with the thoughts of the Wahhabis, namely Muhammadiyah. This organization considers the kiai to be filled with superstition and bid'ah, which has led to stagnation among Muslims. There is also Wahabi itself that developed, especially in Sumatra, who applied violence which was then followed by Salafis. Gradually, AI Irsyad and the Islamic Union (Persis) also appeared which rejected tahlil, grave pilgrimages, salvation, offerings, which were considered shirk and bid'ah. (Moesa, 2007).

At that time, the kiai from traditionalist Islam did not yet have full strength in overcoming the spread of Reformed Islam in Indonesia. Finally, Kiai Abdul Wahab Hasbullah organized traditionalist Islam and collaborated with Nationalist figures, then encouraged Kiai Hasyim Asy'ari to establish an organization for Ulama and traditionalist Islam. Initially Kiai Hasyim Asy'ari refused, but gradually he accepted. Then the Hijaz Committee was formed which aims to represent them in protecting the preservation of the orthodox sects and the activities of the tarekat in Hijaz (now Saudi Arabia). However, on January 31, 1926 the Hijaz Committee changed its name to Nahdlatoel Oelama (NO), an organization that represented traditionalist Islam. (Feillard, 1997). The main purpose of the founding of NU in 1926 was to create a link between ulama who adhere to the four Sunni schools of thought and research religious textbooks to find out whether they contain reformist thoughts or not. Other goals are to do charity, education, promote agriculture, and trade (Feillard, 1997).

Entering the New Order era, NU played a key role in the gradual transfer of power after General Soeharto managed to crush the G30S in just a few days. In addition to the 
participation of radical activists in student demonstrations in 1966, NU also played a very important role in the constitutional takeover of power by general Suharto. For the generals who emphasized the validity of the transfer of power, NU was the only partner that could be used as a foundation of hope. The National Party was too closely related to Soekarno, Masyumi became a party that was banned in 1960 and supervised by the government, while other parties were too small to play a role. (Muhtadi, 2004).

\section{NU Today}

The 27th NU Congress in Situbondo was also very interesting. This is because, first, the decision to return to the 1926 khittah was made, which meant that NU was no longer in practical politics anymore. Second, at this congress, for the first time Abdurrahman Wahid was elected as the General Chair of the Tanfidziyah Board of the Nahdlatul Ulama (PBNU) Executive for the 1984-1989 period. Gus Dur's presence in this organization is important to note, at least because he has given his own color, especially because of Gus Dur's personal character and his unique approach in bringing $\mathrm{NU}$ into the socio-political discourse in Indonesia. The kiai also supported NU's youth initiative, because basically the idea of returning to the 1926 khittah meant returning the ulama's position to an even bigger role. Because NU is involved in practical political struggles, a number of ulama have abandoned their public missions because they were tempted by a power struggle. (Wahid, 2006).

Therefore, NU has the responsibility to anticipate anything that disturbs the statereligion formulation it holds. To cite an example, one of the things that was considered to have disturbed the formulation was the Islamic Khilafah doctrine. The doctrine championed by $\mathrm{HTI}$ activists tries to match, even replace the position of the concept of a nation state which is already considered final in Indonesia. No doubt, this "defiant" signal from the HTI group had made the elites of a number of socio-religious organizations, especially $\mathrm{NU}$, become nervous and accused him of being a treason organization that lives by joining democracy. From here, the discourse of "transnational Islam" rolls more broadly, as if it carries an ideological nuance that threatens the existence of religious organizations that were born from the struggle for authentic Indonesians locality. (Hilmy, 2011).

In the view of the current NU elite, the grounding of Islamic values is a goal that needs to be strived for continuously. Within that framework, NU enforces the rule of 'goals and ways of achieving them' (al-ghayah wa al-wasa'il); the purpose of the law will always remain, but the ways of achieving it can change with the dynamics of the times. From these principles, it can be understood that as long as the goal of grounding Islamic values can still be pursued in a country, even though it is not an Islamic state, then that country can still be accepted. This explains the compromise of NU's attitude towards the nation-state and its rejection of 
the establishment of an Islamic state which is considered to only lead to the disintegration of the nation. On another view, religion today is expected not only to be trapped in ritualism. The dimensions of culture and art serve as pillars of humanitarian attitudes which cannot be separated from religion. Religion runs to fill humanity without any cultural touches that seem dry, hard, and rigid (Asmar, 2020).

\section{CONCLUSION}

$\mathrm{NU}$ as one of the organizations striving for the development of civil society in Indonesia is considered capable of harmonizing Islam with culture. Islam appears with a soft face, which promotes peace in society. The harmony of religious and cultural relations as a characteristic of NU's religious understanding has given birth to religious views and behaviors that are unique to Indonesia. NU believes that Islamic values can be implemented without having to wait or through formal institutions such as the Islamic state. NU idealizes the implementation of the substance of Islamic values in society rather than idealizing institutions. Even the presence of formal institutions is not a guarantee for the realization of Islamic values in society, as occurs in countries that declare themselves as Islamic countries. It is in this context that $\mathrm{NU}$ is able to build work sincerity by crossing borders without religious formalities, both in cooperation with ukhuwwah Islamiyah (brotherhood among Muslims), ukhuwwah wataniyah (brotherhood of nations) and ukhuwwah bashariyah (brotherhood of fellow human beings).

Here it is clear that NU today is struggling to maintain Indonesia's existence, which is essentially a struggle to maintain the existence of Islam itself. Fahal, min easy. In addition, the role of culture, but does not close itself from development or in other words Almuhafadhatu 'alal qadimi as sholeh wal akhdu bi aljadid ilashlah (Maintaining the good old and taking the new is better). Where we can see the NU side is still trying to spread Islam ramat lil naturalin. On the other hand, it tries to organize education in which the pesantren are given space to contribute to the fields of technology, science, and other modern sciences.

\section{REFERENCES}

Abdullah, M. A. (1996). Studi Agama, Normativitas dan Historisitas. Pustaka Pelajar.

Anam, C. (1999). Pertumbuhan Dan Perkembangan NU. Bisma Satu Surabaya.

Asmar, A. (2018). Genealogi dan Strategi Dakwah Kultural NU. Http://Islamica.Uinsby.Ac.Id/Index.Php/Islamica/Article/View/574, 13(1). https://doi.org/https://doi.org/10.15642/islamica.2018.13.1.164-183

Asmar, A. (2020). DAKWAH LESBUMI NU: SAPTAWIKRAMA. ISLAM NUSANTARA, 4(1), 
17-29. https://doi.org/10.33852/jurnalin.v4i1.172

Baharun, H., \& Mundiri, A. (2011). Metodologi Studi Islam: Percikan Pemikiran Tokoh Dalam Membumikan Agama. Ar-Ruzz Media.

Bakar, A. A. (1957). Sejarah Hidup KH. A. Wahid Hasyim dan Karangan Tersiar. Panitia Buku Peringatan KH. A. Wahid Hasyim.

Bisri, A. M. (2002). Kumpulan Kolom dan Artikel Abdur Rahman Wahid selama Era Lengser. LKiS.

Feillard, A. (1997). Gus Dur, NU, dan Masyarakat Sipil. LKiS.

Hilmy, M. (2011). Akar-Akar Transnasionalisme Islam Hizbut Tahrir Indonesia (HTI). ISLAMICA: Jurnal Studi Keislaman, 6(1), 1-13.

Karim, M. A. (2014). Islam Nusantara. Gramasurya.

Maarif, A. S. (2017). Islam Dan Pancasila Sebagai Dasar Negara. Mizan.

Moesa, A. M. (2007). Nasionalisme Kiai; Konstruksi Sosial berbasis Agama. LKiS.

Muhtadi, A. S. (2004). Komunikasi Nahdlatul Ulama; Pergulatan Pemikiran Politik Radikal dan Akomodatif. LP3ES.

Ridwan, N. K. (2010). NU \& Bangsa 1914-2010: Pergulatan Politik dan Kekuasaan. Ar-Ruzz Media.

Siddiq, A. K. (1985). Islam, Pancasila dan Ukhuwah Islamiyyah. Lajnah wa al-Nars PBNU dan Penerbit Sumber Barokah.

Siradj, S. A. (2015). Islam Sumber Inspirasi Budaya Nusantara Menuju Masyarakat Mutamaddin. LTN NU.

Syarifuddin, A. (2009). Ushul Fiqh. Pranada Group.

Wahid, A. (2006). Islamku, Islam Anda, Islam Kita: Agama Masyarakat Negara Demokrasi. The Wahid Institution.

Yunanto, S. (2018). Islam Moderat VS Islam Radikal. Media Pressindo.

Zada, K., \& Sjadzili, A. F. (2010). Nahdlatul Ulama: Dinamika Ideologi dan Politik Kenegaraan. PT Kompas Media Nusantara.

Zahro, A. (2004). Lajnah Bahtsul Masa'il 1926-1999. LkiS Pelangi Aksara. 